\section{Fla. 7946 Tomato Breeding Line Resistant to Fusarium oxysporum f.sp. lycopersici Races 1, 2, and 3}

\author{
J.W. Scott \\ Gulf Coast Research and Education Center, 5007 60th Street East, University \\ of Florida, Bradenton, FL 34203
}

Additional index words. blossom-end rot, cultivar, disease resistance, fruit size, fusarium wilt, Lycopersicon esculentum

Fla. 7946 is a fresh-market tomato (Lycopersicon esculentum Mill.) breeding line resistant to the three known races of Fusarium oxysporum Schlecht. f.sp. lycopersici (Sacc.) Snyder \& Hansen, the incitant of fusarium wilt of tomato. It carries the dominant $I-3$ gene that confers resistance to race 3 and the Got-2 allozyme linked to I-3 (Bournival et al., 1989). Fla. 7946 has smoother blossom scars, larger fruit, and is less prone to blossom-end rot than Fla. 7547, a Fusarium race 3 resistant breeding line released earlier (Scott and Jones, 1995). Like Fla. 7547, it has the high lycopene crimson $\left(\operatorname{cg}^{c}\right)$ gene. It has performed well in hybrid combinations including Fla. 7973 and 'Solar Fire' and should be useful to tomato breeders for making commercial hybrids or developing new inbreds.

\section{Origin}

Fla. 7946 was increased in the $\mathrm{F}_{9}$ generation after two modified backcrosses with Fla. 7547 (Fig. 1). Fla. 7547 was the donor of the $I-3$ and $o g^{c}$ genes. Inbreds were advanced to the $\mathrm{F}_{7}$ generation before each of the crosses to Fla. 7547. The $\mathrm{F}_{7}$ derived from 7344 and 7396 carried the $n-4$ nipple gene that originated from NC 8276. This gene was not carried forward in the $\mathrm{F}_{7}$ derived from the first cross with 7547 . The $F_{7}$ had a smooth blossom scar however, and did carry the $\operatorname{og}^{c}$ gene. It also had a strong vine. The fruit shape was improved after the second cross with Fla. 7547 and selection for larger fruit size, blossom scar smoothness, and a lack of blossom-end rot was done.

\section{Description}

Fla. 7946 has a medium size, determinate vine $(s p)$ with better fruit cover than Fla. 7547. Like Fla. 7547, the foliage is dark green and has an open type growth habit, but the vine is larger and less open than that of Fla. 7547. Fruit set is concentrated and good under most conditions, but not under heat stress. In Spring 2000, yields were comparable to the other genotypes

Received for publication 28 Jan. 2003. Accepted for publication 18 July 2003. Agricultural Experiment Station Journal Series no. R-09196.I thank Karen Pearce and John Petti for technical assistance. tested including Florida 47, the predominant cultivar presently grown in Florida (Table 1). Yield in Spring 2003 was significantly higher than Florida 47 and comparable to previous breeding line releases (Table 1). The fruit size of Fla. 7946 was not quite significantly more than that of Fla. 7547 in the Spring 2000 trial, but it was significantly larger than Fla. 7547 in

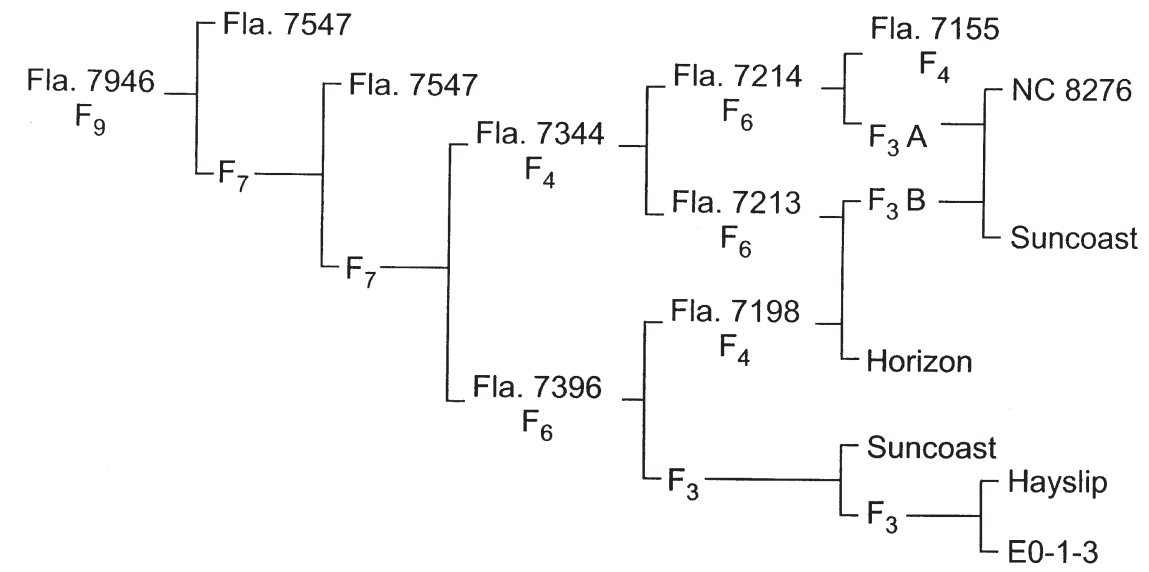

Fig. 1. Pedigree of Fla.7946.

Table 1. Marketable yield, fruit size, cull percentage, and fruit with blossom-end rot for selected tomato genotypes in Spring 2000 and 2003 at Bradenton, Fla.

\begin{tabular}{|c|c|c|c|c|c|c|c|}
\hline \multirow[b]{2}{*}{ Genotype } & \multicolumn{2}{|c|}{$\begin{array}{l}\text { Marketable yield } \\
\text { (kg/plant) }\end{array}$} & \multicolumn{2}{|c|}{ Fruit size } & \multicolumn{2}{|c|}{ Cull } & \multirow{2}{*}{$\begin{array}{c}\begin{array}{c}\text { Blossom-end rot } \\
\text { (no./plant) }\end{array} \\
2000\end{array}$} \\
\hline & 2000 & 2003 & 2000 & 2003 & 2000 & 2003 & \\
\hline Fla. 7771 & $5.7 \mathrm{a}^{\mathrm{z}}$ & $4.4 \mathrm{a}$ & $139 \mathrm{a}$ & $151 \mathrm{~b}$ & $16 \mathrm{~b}$ & 24 & $1.2 \mathrm{~b}$ \\
\hline Equinox & $4.6 \mathrm{a}$ & --- & $156 \mathrm{a}$ & --- & $24 \mathrm{~b}$ & --- & $3.7 \mathrm{~b}$ \\
\hline Florida 47 & $4.5 \mathrm{a}$ & $3.2 \mathrm{~b}$ & $172 \mathrm{a}$ & $201 \mathrm{a}$ & $14 \mathrm{~b}$ & 25 & $1.5 \mathrm{~b}$ \\
\hline Fla. 7946 & $3.7 \mathrm{ab}$ & $4.6 \mathrm{a}$ & $154 \mathrm{ab}$ & $192 \mathrm{a}$ & $16 \mathrm{~b}$ & 16 & $2.3 \mathrm{~b}$ \\
\hline Fla. 7547 & $1.6 \mathrm{~b}$ & $3.7 \mathrm{ab}$ & $120 \mathrm{~b}$ & $157 \mathrm{~b}$ & $63 \mathrm{a}$ & 17 & $11.5 \mathrm{a}$ \\
\hline
\end{tabular}

${ }^{2}$ Mean separation in columns by Duncan's multiple range test at $P \leq 0.05$. No letters $=$ no sigificant difference.

Table 2. Firmness and fruit color for selected tomato genotypes in Spring 2000 at Bradenton, Fla.

\begin{tabular}{|c|c|c|c|c|c|}
\hline \multirow[b]{2}{*}{ Genotype } & \multirow{2}{*}{$\begin{array}{c}\text { Firmness }^{\mathrm{z}} \\
\text { (mm deformation) }\end{array}$} & \multicolumn{2}{|c|}{ External fruit color ${ }^{y}$} & \multicolumn{2}{|c|}{ Internal fruit color ${ }^{y}$} \\
\hline & & $\mathrm{L}$ & Hue angle & $\mathrm{L}$ & Hue angle \\
\hline Florida 47 & 4.2 & $46.5 \mathrm{ab}^{\mathrm{x}}$ & 59.0 & $46.4 \mathrm{ab}$ & $58.2 \mathrm{a}$ \\
\hline Equinox & 4.4 & $46.5 \mathrm{a}$ & 58.1 & $45.7 \mathrm{~b}$ & $56.2 \mathrm{~b}$ \\
\hline Fla. 7946 & 4.6 & $45.6 \mathrm{ab}$ & 58.6 & $41.8 \mathrm{c}$ & $51.8 \mathrm{c}$ \\
\hline Fla. 7547 & 4.7 & $46.4 \mathrm{ab}$ & 59.1 & $41.4 \mathrm{c}$ & $52.8 \mathrm{c}$ \\
\hline Fla. 7771 & 4.8 & $45.8 \mathrm{~b}$ & 59.4 & $47.6 \mathrm{a}$ & $58.6 \mathrm{a}$ \\
\hline
\end{tabular}

${ }^{2}$ Determined with a pressure tester using a $1-\mathrm{kg}$ weight for $5 \mathrm{~s}$ with a $1.5-\mathrm{cm}$ diameter fruit contact plate. Pressure applied over a locule in equatorial plane.

'Data taken with a Minolta CR-300 chroma meter; higher L numbers indicate lighter color (value); lower hue angles indicate more red color (hue).

${ }^{\mathrm{x}}$ Mean separation in columns by Duncan's multiple range test at $P \leq 0.05$. No letters $=$ no sigificant difference. 
bursting of ripe fruit under some stress conditions. Hybrids with Fla. 7946 have less radial and cuticle cracking than most hybrids when grown under rainy conditions (Scott, unpublished observations). Fruit ripen well without white tissue, blotchy ripening, or graywall. There is some zippering, but generally on a low percentage of fruit. Blossom-end rot has been problematic on all tomatoes with the $I-3$ gene. Fla. 7946 has less of it than Fla. 7547

Table 3. Response of tomato genotypes 3 weeks after inoculation with Fusarium oxysporum f.sp. lycopersici race $3\left(10^{7}\right.$ spores $\left./ \mathrm{mL}\right)$ at the cotyledon stage in a Fall 1999 greenhouse experiment.

\begin{tabular}{lccc}
\hline & $\begin{array}{c}\text { Total } \\
\text { plants } \\
\text { (no.) }\end{array}$ & $\begin{array}{c}\text { Healthy } \\
\text { plants } \\
\text { (no.) }\end{array}$ & $\begin{array}{c}\text { Diseased } \\
\text { plants } \\
\text { (no.) }\end{array}$ \\
\hline Fla. 7946 & 40 & 40 & 0 \\
Fla. 7547 & 48 & 47 & 1 \\
Horizon & 48 & 1 & 47 \\
\hline
\end{tabular}

${ }^{\mathrm{z}}$ Fla. 7547 is the resistant control $(I-3 / I-3)$ and 'Horizon' is the susceptible control (I-1/I-1, I-2 / $I-2, i-3 / i-3)$. as was seen in the Spring 2000 trial (Table 1). In that trial the blossom-end rot was similar to that of genotypes other than Fla. 7547. Under most conditions, blossom-end rot will not be a significant problem for Fla. 7946, but there may be some since the association of blossomend rot with $I-3$ has not been eliminated. The blossom-end rot differences between Fla. 7547 and Fla. 7946 are not always as dramatic as those depicted in Table 1 as Fla. 7547 is not usually that susceptible.

Disease resistances. In addition to fusarium wilt race 3 resistance (Table 3), Fla. 7946 is resistant to fusarium wilt races 1 and 2, verticillium wilt race 1 caused by Verticillium dahliae Kleb., and gray leafspot caused by Stemphyllium solani Weber. Although not verified, it is likely that Fla. 7946 has resistance to fusarium wilt races 1 and 2 due to genes on chromosome 7 linked to $I-3$ and due to the $I-2$ and $I$ genes on chromosome 11 (Mueller, L. 2000.; Bournival et al., 1989). All recent inbreds in the pedigree have I and I-2. Fla. 7946 had more susceptibility to bacterial spot (Xanthomonas campestris pv. vesicatoria (Doidge) Dye) than some other susceptible inbreds, including Fla. 7771 and 'Equinox' (data not shown).

\section{Availability}

Fla. 7946 is a breeding line release. Distribution of seed is through the Florida Foundation Seed Producers, P.O. Box 309, Greenwood, FL 32443.

\section{Literature Cited}

Bournival, B.L., J.W. Scott, and C.E. Vallejos. 1989. An isozyme marker for resistance to race 3 of Fusarium oxysporum f.sp.lycopersici in tomato. Theor. Appl. Genet. 78:489-494.

Scott, J.W. and John Paul Jones. 1995. Fla. 7547 and Fla. 7481 tomato breeding lines resistant to Fusarium oxysporum f.sp. lycopersici races 1, 2, and 3. HortScience 30(3):645-646.

Scott, J.W. 1999. Tomato plants heterozygous for fusarium wilt race 3 resistance develop larger fruit than homozygous resistant plants. Proc. Fla. State Hort. Soc. 112:305-307.

Mueller, L. 2000. The Solanaceae Genomics Network. 30 June 2003. <http://www.sgn.cornell. edu/cgi-bin/mapviewer/mapTop.pl?map_id=1> 